\title{
Doktoraty honoris causa Uniwersytetu Ekonomii i Prawa "KROK" $w$ Kijowie oraz Narodowego Uniwersytetu Pedagogicznego im. G.S. Skoworody w Charkowie dla Rektora Krakowskiej Akademii im. Andrzeja Frycza Modrzewskiego profesora Jerzego Malca
}

Doctorates bonoris causa of the "KROK" University of Economics and Law in Kiev and the National Pedagogical University G.S. Skoworoda in Kharkiv for the Rector of the Krakow Academy Andrzej Frycz Modrzewski

Professor Jerzy Malec

W dniu 2 marca 2018 roku na Uniwersytecie Ekonomii i Prawa „KROK” w Kijowie odbyła się uroczystość nadania tytułu doktora honoris causa rektorowi Krakowskiej Akademii im. Andrzeja Frycza Modrzewskiego prof. zw. dr. hab. Jerzemu Malcowi. Obie uczelnie łączy wieloletnia współpraca. Laudację wygłosił prof. Taras Finikow, były wiceminister oświaty i szkolnictwa wyższego Ukrainy. Zaprezentował on sylwetkę naukową prof. J. Malca, jego znaczący dorobek w zakresie historii państwa i prawa oraz historii administracji, liczący ponad 150 publikacji oraz kilkanaście książek, a także zaangażowanie na rzecz reformy szkolnictwa wyższego w Polsce i rozszerzenia współpracy z uczelniami Ukrainy, które to działania prowadzi od kilkunastu lat.

Wieloletnia współpraca z Narodowym Uniwersytetem Pedagogicznym im. G.S. Skoworody w Charkowie zaowocowała drugim w tym roku doktoratem honoris causa dla prof. J. Malca. Doktorat przyznany 30 października 2017 roku został wręczony 24 kwietnia 2018 roku podczas uroczystego posiedzenia Senatu Krakowskiej Akademii. Laudację wygłosiła prof. Ludmiła Sztefan, reprezentująca rektora charkowskiej uczelni prof. I.F. Prokopenkę, ona też wręczyła prof. J. Malcowi dyplom doktora honorowego oraz statuetkę przedstawiającą patrona uczelni.

W laudacji podkreślono, że Profesor Jerzy Malec w latach 2005-2008 pełnił funkcję przewodniczącego Konferencji Rektorów Zawodowych Szkół Polskich. Jest także 
członkiem Komitetu Nauk Prawnych PAN. Przyczynił się znacząco do rozwoju współpracy naukowej polsko-ukraińskiej, a także czynnie uczestniczył w pracach nad reformą systemu szkolnictwa wyższego na Ukrainie jako konsultant i doradca. Jest odznaczony Krzyżem Kawalerskim i Komandorskim Orderu Odrodzenia Polski, a w 2011 roku otrzymał tytuł profesora honorowego October 6 University w Egipcie. 